\title{
SADRŽAJNA OBRADA \\ NEVJERODOSTOJNE STRUČNE GRAĐE \\ U NARODNIM KNJIŽNICAMA
}

\author{
SUBJECT ANALYSIS OF UNRELIABLE \\ NONFICTION MATERIALS IN PUBLIC LIBRARIES
}

\section{Božica Dragaš}

Knjižnice grada Zagreba

bozica.dragas@kgz.hr

Snježana Ercegovac

Knjižnice grada Zagreba

snjezana.ercegovac@kgz.hr

Marija Turković Kordić

Knjižnice grada Zagreba

marija.turkovic.kordic@kgz.hr

UDK / UDC [025.4: 027.022]:070.16

Izvorni znanstveni rad / Original scientific paper

Primljeno / Received: 24. 8. 2020.

Prihvaćeno / Accepted: 2. 11. 2020.

\section{Sažetak}

Cilj. Cilj je rada dati uvid u aktualnu praksu sadržajne obrade nevjerodostojne stručne građe u hrvatskim narodnim knjižnicama te propitati mogućnosti da se postojećim alatima sadržajne obrade napravi razlika između takve građe i građe koja je stručno i znanstveno utemeljena.

Pristup/metodologija. Sadržajna obrada stručne građe u narodnim knjižnicama tematizira se s obzirom na ulogu knjižnica u sprječavanju širenja lažnih vijesti, dezinformacija i pseudoznanstvenih ideja. Potom se razlažu obilježja znanstveno neutemeljene stručne građe te se aktualna praksa njezine sadržajne obrade ilustrira s pet primjera publikacija čije su klasifikacijske oznake, predmetne odrednice i anotacije pregledane pre-

Vjesnik bibliotekara Hrvatske 63, 1-2(2020), 253-282 ISSN 0507-1925 
traživanjem mrežnih kataloga narodnih knjižnica okupljenih u trima velikim skupnim katalozima s obzirom na knjižnični softver koji koriste: CROLIST, MetelWIN i ZaKi.

Rezultati. Kataložni zapisi odabranih primjera publikacija upućuju na to da se u hrvatskim narodnim knjižnicama klasifikacijskim oznakama, predmetnim označivanjem i anotacijama ne pravi razlika između nevjerodostojne stručne građe i građe utemeljene na suvremenim znanstvenim paradigmama, što korisnike izlaže mogućim dezinformacijama pri pretraživanju stručne građe u slobodnom pristupu jednako kao i u online okruženju.

Originalnost/vrijednost. S obzirom na važnost knjižnica u promicanju vjerodostojnih informacija i suzbijanju lažnih vijesti, ovaj rad upućuje na nužnost promišljanja o aktualnoj praksi sadržajne obrade nevjerodostojne stručne građe, čija je produkcija intenzivirana posljednjih desetljeća te ona čini dio zbirki stručne građe narodnih knjižnica. Premda na opasnost od širenja pseudoznanstvenih informacija znanstvenici upozoravaju dugi niz godina, a s problemima vezanim uz tu temu knjižničari se susreću svakodnevno u radu s korisnicima, ovo je prvi rad koji tematizira sadržajnu obradu takve građe u hrvatskim narodnim knjižnicama te u vezi s tim upozorava na društvenu odgovornost knjižničara.

Ključne riječi: anotacije, nevjerodostojna stručna građa, predmetno označivanje, pseudoznanost, Univerzalna decimalna klasifikacija

\section{Abstract}

Aim. The aim of the paper is to give an overview of the current approaches to the subject analysis of unreliable nonfiction materials in the Croatian public libraries, and to research the potential of the existing subject analysis tools to differentiate between such materials and those that are based on scientific and expert knowledge.

Approach/methodology. In this paper, the subject analysis of unreliable nonfiction materials in public libraries is approached in relation to the role of libraries in preventing the spread of false news, disinformation, and pseudoscientific ideas. Subsequently, the characteristics of scientifically unreliable publications are examined, and current approaches to the subject analysis of such materials are illustrated through five publications whose classification classes, subject headings, and annotations were examined by browsing the online catalogues of the public libraries combined into three extensive union catalogues according to their library software: CROLIST, MetelWIN, and ZaKi.

Results. The catalogue records of the selected publications reveal that there is no distinction made in the Croatian public libraries between unreliable nonfiction materials and materials based on current scientific paradigms through the classification class numbers, the assigned subject headings, and annotations, which exposes users to possible disinformation when browsing nonfiction materials in both open-stack collections and online. 
Originality/value. Taking into account the importance of libraries in promoting reliable information and preventing false news, this paper indicates the need to reevaluate the current procedures of the subject analysis of unreliable nonfiction materials whose production has intensified during the last decades and which constitute a portion of the nonfiction collections in public libraries. Even though scientists have been warning about the dangers of the spread of pseudoscientific information for a number of years, and librarians encounter issues related to this topic in the interaction with users on a daily basis, this is the first paper that focuses on subject analysis of such materials in the Croatian public libraries and emphasizes the social responsibility of librarians regarding this issue.

Keywords: annotations, assigning subject headings, pseudoscience, Universal Decimal Classification, unreliable nonfiction materials

„,...[ljudi] vjeruju da je 'Na rubu znanosti' znanstvena emisija jer Krešimir Mišak tako kaže. (...) kao što vjeruju da je David Icke znanstvenik zato što knjižničari ne znaju kud bi s njegovim knjigama pa ih stavljaju na policu na kojoj piše: općenito - znanost. "1

\section{Uvod}

U eseju „Odgovor na pitanje: Što je prosvjetiteljstvo?“2 objavljenom 1784. godine u časopisu „Berlinische Monatsschrift“, Kant je ustvrdio da je prosvjetiteljstvo bilo „,čovjekov izlazak iz samoskrivljene nezrelosti“, pri čemu se ,nezrelost" odnosi na čovjekovu nesposobnost da se samostalno služi svojim razumom. ${ }^{3}$ Prosvjetiteljstvo je predvidjelo da će čovječanstvo sve oblike predrasuda $i$ neznanja zamijeniti znanstvenom spoznajom. I doista, zamah prirodnih znanosti, obrazovanja, sekularizacije i modernizacije društva, koji suvremena civilizacija baštini od prosvjetiteljstva, ne samo da otad nije posustao nego je od sredine 20 . stoljeća razvojem tehnologije dodatno dobio na snazi. Međutim, unatoč porastu obrazovanosti, pismenosti i informiranosti stanovništva te unatoč brojnim znanstveno-tehnološkim postignućima, posljednjih nekoliko desetljeća u porastu je širenje pseudoznanstvenih ideja i lažnih informacija. Rezultat je to razvoja suvre-

\footnotetext{
1 Hrupec, D. Protiv nadnaravnoga: razmišljanja o istini, znanosti i knjigama. Zagreb: Kruzak, 2016. str. 11.

2 Kant, I. Was ist Aufklärung? // Utopie kreativ 159, 1(2004), str. 5-10. [citirano: 2020-04-05]. Dostupno na: https://www.rosalux.de/fileadmin/rls uploads/pdfs/159 kant.pdf.

3 Usp. Prosvjetiteljstvo. // Hrvatska enciklopedija. [citirano: 2020-04-05]. Dostupno na: https:// www.enciklopedija.hr/Natuknica.aspx?ID=50722.
} 
menih komunikacijskih tehnologija, ,demokratizacije“ znanja i pada povjerenja u tradicionalne institucije, pa tako i u znanost.

Govoreći o znanosti i pseudoznanosti u društvima postmoderne, Pavić revitalizaciju pseudoznanstvenih spoznaja povezuje s obilježjima postmodernih društava kao društava rizika te $\mathrm{s}$ nemogućnošću znanosti da pruži sveobuhvatne svjetonazore. ${ }^{4} \mathrm{U}$ postmodernim društvima obećanje ekonomskog blagostanja praćeno je siromaštvom i dehumanizirajućim radom te ekološkim krizama, što život čini stresnim i opasnim. Moderna društva udaljuju se od izvjesnosti tradicije i otvaraju se prema budućnosti, a ona je po definiciji nepredvidljiva i neizvjesna, što može dovesti do tjeskobe. Za razliku od znanosti, pseudoznanost može ponuditi jasan svjetonazor i osnažiti ljude u uvjerenju da mogu kontrolirati svoje okolnosti: alternativna medicina nudi mogućnost kontrole vlastitog zdravlja, astrologija nudi mogućnost kontrole života, dok teorije zavjere tvrde da su povijesni događaji rezultat međunarodnih aktivnosti ,zlih“ osoba.

Dio odgovornosti za širenje pseudoznanosti pripisuje se i slabostima aktualne prakse znanstvenog rada i objavljivanja rezultata istraživanja. U tekstu „Dva načina razotkrivanja znanstvene prijevare" Polšek daje pregled kritika koje se odnose na upitnost sustava recenziranja, praksu neponavljanja istraživanja drugih znanstvenika zbog neisplativosti, poliranje znanstvenih podataka kako bi se uklopili u unaprijed zamišljenu hipotezu, potisnuta istraživanja, objavu članaka s neprovjerenim informacijama radi prodaje znanstvenog časopisa, financijske prijevare u znanosti, znanstveni karijerizam itd. ${ }^{5}$ Sve to utječe na pad povjerenja u znanost i znanstvene institucije, a time i osnažuje razvoj pseudoznanstvenih i antiznanstvenih teorija.

No jedna od ključnih okosnica bujanja pseudoznanosti jest profit. Kao ilustraciju ,industrije kontraznanja“ britanski sociolog Thompson iznosi primjere svjetskih uspješnica prodanih u višemilijunskim nakladama, a čiji su autori samoprozvani stručnjaci: Rhonda Byrne, Patrick Holford i Gavin Menzies. ${ }^{6}$ Primjerice, premda su publikaciju R. Byrne „Tajna“, o zakonu privlačnosti prema kojemu zdravstveno ili financijsko blagostanje pojedinca ovisi isključivo o njegovim osobnim mislima, popratile loše kritike i stručnjaci su upozoravali da je riječ o „ozbiljno opasnoj“ knjizi koja je i u etičkom smislu „za svaku osudu“,7 ona je prevedena na više od 50 jezika i prodana u više od 34 milijuna primjeraka. ${ }^{8}$

\footnotetext{
4 Usp. Pavić, Ž. Science and pseudoscience in postmodern societies. // Informatologia 46, 2(2013), str. 145-153.

5 Usp. Polšek, D. Two ways of dealing with scientific fraud. // Revija za sociologiju 28, 3-4(1997), str. 163-173.

6 Usp. Thompson, D. Kontraznanje: kako smo podlegli teorijama zavjere, nadriliječništvu, pseudoznanosti i kvazipovijesti. Zagreb: Algoritam, 2009. Str. 99-141.

7 Isto, str. 101.

8 Rhonda Byrne: biography of the author. [citirano: 2020-05-18]. Dostupno na: https://www. thesecret.tv/about/rhonda-byrnes-biography/.
} 
Zbog količine lažnih vijesti, dezinformacija i pseudoznanstvenih informacija, stručnjaci danas govore o razdoblju ,post-istine“,, a na opasnost tog fenomena kao pandemije 21. stoljeća znanstvenici, zabrinuti za nespremnost društva na tu pojavu, sve glasnije upozoravaju javnost. ${ }^{10}$

Dosadašnja teorijska i praktična nastojanja knjižničarske zajednice usmjerena na osnaživanje informacijskih kompetencija korisnika ticala su se ponajprije izvora informacija u digitalnom okruženju, ali načela uspješnog pretraživanja i vrednovanja informacija vrijede i za tiskane publikacije. Stoga se odgovornost knjižničara tiče i sadržajne obrade stručne građe koja je dio knjižničnih zbirki, osobito u kontekstu korisničkog pretraživanja knjižničnih mrežnih (online) kataloga pomoću klasifikacijskih oznaka i predmetnih odrednica.

Budući da termin ,pseudoznanost“" nije opisan u hrvatskim rječnicima i enciklopediji, usto je pejorativno obilježen i tvorbeno nije u duhu hrvatskoga jezika, ${ }^{11}$ u daljnjem tekstu za imenovanje takve knjižnične građe upotrebljava se izraz „znanstveno neutemeljena stručna građa“ te izraz „nevjerodostojna stručna građa“ ${ }^{12}$ analogno s već uvriježenim pojmom ,(ne)vjerodostojnih izvora informacija“.

Uvid u aktualnu praksu sadržajne obrade nevjerodostojne knjižnične građe u hrvatskim narodnim knjižnicama u ovom se radu daje na temelju pregleda sadržajne obrade pet ilustrativnih primjera publikacija: Bučević, Ana. Biti i imati: promjenom vibracije do financijske slobode. Split: Kontakt plus, 2018.; Pepeljnjak, Branko. Znanstveno - potpuno objašnjenje čovjeka: sreća, stres, osjećaji i razum. Zagreb: Vlast. nakl., 2018.; Royal, Lyssa; Priest, Keith. Prizma Lyre: istraživanje ljudskog galaktičkog podrijetla. Bregana: Harša, 2018.; Vujnović, Darko. Zbogom cjepiva: štetna i neučinkovita. Zagreb: Omega lan, 2018.; Vampovac, Zdravko. Maleni ispod zvijezda: knjiga o znanstvenim obmanama. Vodice: Vlast. nakl., $2018 . .^{13}$

\footnotetext{
9 Engl. post-truth - odnosi se na situacije u kojima ljudi radije prihvaćaju argumente utemeljene na vlastitim emocijama i vjerovanjima nego one utemeljene na činjenicama. Usp. Cambridge Dictionary. [citirano: 2020-05-18]. Dostupno na: https://dictionary.cambridge.org/dictionary/english/post-truth. Izraz se u hrvatskom jeziku pojavljuje u različitim sintagmama: ,postčinjenična era“, „vrijeme poslije istine“, „doba post-istine“.

10 U Hrvatskoj to već više od desetljeća, nizom medijskih napisa, blogova, javnih tribina i publikacija, čine znanstvenici Saša Ceci, Dario Hrupec, Igor Rončević i Dejan Vinković.

11 U Hrvatskom jezičnom savjetniku navodi se da su imenice s prefiksom pseudo- pejorativno obilježene te da tom prefiksu od domaćih prefiksa odgovaraju: laži-, nadri-, nazovi- i pa-. Usp. Barić, E.; L. Hudeček; N. Koharović; M. Lončarić; M. Lukenda; M. Mamić; M. Mihaljević i suradnici. Hrvatski jezični savjetnik. Zagreb: Institut za hrvatski jezik i jezikoslovlje: Pergamena: Školske novine, 1999. Str. 210. Autorice rada nijednu od mogućih varijanti nisu prepoznale kao neutralan izraz koji bi odgovarao kontekstu ovoga rada.

12 Pojam „stručna građa“ obuhvaća svu knjižničnu građu osim književnosti.

13 Navedeni naslovi zatekli su se kao ogledni primjerci u istom razdoblju u odjelu nabave i obrade knjižnice u kojoj rade autorice članka (svih pet objavljeno je iste godine), te su ih autorice, u
} 
S gledišta sadržajne obrade, kataložni zapisi navedenih publikacija pregledani su pretraživanjem mrežnih kataloga narodnih knjižnica okupljenih u trima velikim skupnim katalozima s obzirom na knjižnični softver koji koriste: CROLIST, MetelWIN, ZaKi.

\section{Uloga knjižničara u sprječavanju širenja lažnih vijesti i nevjerodo- stojnih informacija}

Polazeći od pretpostavke da je jedna od temeljnih funkcija knjižnice osiguravanje dostupnosti i promicanje pouzdanih i vjerodostojnih informacija kao temelja za ostvarenje demokracije i društvene dobrobiti, knjižničari su suočeni s izazovom svoje uloge u suzbijanju fenomena post-istine.

Poricanje postojanja činjenične istine, sumnja u dosege znanosti i relativizacija stručnosti, davanje prednosti osobnim stavovima, teorijama i vrijednosnim prosudbama, antiteza je onoga za što se informacijske znanosti i knjižničarstvo kao profesija zalažu. ${ }^{14}$

Špiranec navodi da u suzbijanju fenomena post-istine knjižnice imaju ključnu ulogu, između ostalog, i zbog toga što javnost percipira knjižnice kao pouzdane i vjerodostojne ustanove koje čuvaju činjenice i znanje - dok povjerenje u mnoge tradicionalne institucije informacija i znanja, poput sveučilišta ili medija erodira, knjižnicama javnost i dalje vjeruje. ${ }^{15}$

Međunarodna knjižničarska udruga IFLA objavila je 2017. godine infografiku „Kako prepoznati lažne vijesti“ kao pomoć korisnicima u snalaženju s nepouzdanim izvorima informacija. U organizaciji Hrvatskoga knjižničarskog društva 2018. godine održan je okrugli stol „Knjižnice i alternativna (druga) istina“ na kojem su sudjelovali stručnjaci iz različitih područja. ${ }^{16}$ Lažne vijesti i nepouzdane izvore informacija tematizirao je i ZKD Forum održan u veljači 2020. godine pod nazivom „Umijeće laganja“ ${ }^{17}$

sklopu promišljanja o temi kojom se ovaj rad bavi, odabrale kako bi pratile na koji su način potom kao prinove sadržajno obrađeni u različitim narodnim knjižnicama.

14 Usp. Bawden, D.; L. Robinson. Supporting truth and promoting understanding: knowledge organization and the curation of the infosphere. // The Occasional Informationist: irregular thoughts on the information sciences. [citirano: 2020-04-05]. Dostupno na: https://theoccasionalinformationist.com/2018/07/17/supporting-truth-and-promoting-understanding-knowledge-organization-and-the-curation-of-the-infosphere/.

15 Usp. Špiranec, S. Knjižnice u dobu post-istine: etičke i epistemološke dileme. // Slobodan pristup informacijama: 18. okrugli stol: zbornik radova / uredile Davorka Pšenica i Annemari Stimac. Zagreb: Hrvatsko knjižničarsko društvo, 2018. Str. 41.

16 18. okrugli stol o slobodnom pristupu informacijama - Knjižnice i alternativna (druga) istina. // Hrvatsko knjižničarsko društvo. [citirano: 2020-05-05]. Dostupno na: https://www.hkdrustvo. $\mathrm{hr} / \mathrm{hr} /$ skupovi/skup/381/.

17 ZKD Forum - Umijeće laganja. // Zagrebačko knjižničarsko društvo. [citirano: 2020-05-05]. Dostupno na: https://zkd.hr/novosti/zkd-forum-umijece-laganja/. 
Navedeno upućuje na to da i međunarodna i hrvatska knjižničarska zajednica prepoznaju potrebu aktivnog uključivanja u suzbijanje širenja lažnih vijesti i nepouzdanih izvora informacija. No sve spomenute aktivnosti, kao i radionice informacijske pismenosti koje se već godinama provode u brojnim hrvatskim narodnim knjižnicama, usmjerene su na pomoć korisnicima pri snalaženju s nepouzdanim izvorima informacija samo u virtualnom okruženju.

Međutim, takvi izvori informacija dio su i knjižničnih fondova narodnih knjižnica. Dok izgradnja zbirki visokoškolskih i specijalnih knjižnica isključuje nabavu stručno i znanstveno neutemeljene građe jer ona ne može udovoljiti stručnim, znanstvenim i obrazovnim potrebama njihovih korisnika, nabavna politika narodnih knjižnica uključit će i nevjerodostojnu stručnu građu jer „narodna knjižnica treba osigurati jednakost pristupa nizu izvora koji zadovoljavaju potrebe korisnika za obrazovanjem, informacijama, razonodom i osobnim razvojem". ${ }^{18}$

Osim kriterija vrijednosti, koji se odnosi na sadržajna i fizička obilježja djela, pri izgradnji knjižnične zbirke u narodnim knjižnicama važan je i kriterij potražnje, koji se odnosi na pretpostavljene ili iskazane potrebe korisnika. Kako ističu Nebesny i Švob, „dok je narodna knjižnica ispunjavala samo odgojne i obrazovne zadaće, selekcija građe bila je 'razumljiv postupak' jer je zbirka imala strogo utilitarnu namjenu. Proširivanje zadaća knjižnice uključivanjem kulturnih, zabavnih i rekreativnih zadaća znatno proširuje okvire zbirke narodne knjižnice. “19

S obzirom na to da fond narodnih knjižnica mora zadovoljavati raznovrsne potrebe svih članova zajednice te se pri nabavi ne provodi cenzura ni prema sadržaju djela ni prema autoru, u knjižničnim su zbirkama zastupljeni i naslovi nevjerodostojne stručne građe, pri čemu su među njima i oni koje su stručnjaci, znanstvenici ili znanstveni novinari ocijenili štetnima i opasnima, poput onih koje spominje Thompson.

Izlažući različite neučinkovite pristupe knjižničarske zajednice fenomenu postčinjeničnog doba, utemeljene na zamisli da je najvažnije osigurati pristup kvalitetnim informacijama, znanjima ili vještinama, Špiranec ističe pogrešnost premise informacijskog deficita prema kojoj je širenje netočnih informacija povezano s nedostatkom ili nedostupnošću istinitih. ${ }^{20}$ Samo „osiguravanje pristupa točnim informacijama neće nužno korektivno djelovati i zaustaviti širenje fenomena post-isti-

\footnotetext{
18 Narodna knjižnica: IFLA-ine i UNESCO-ove smjernice za razvoj službi i usluga / priredila radna skupina Sekcije za narodne knjižnice na čelu s Philipom Gillom. Zagreb: Hrvatsko knjižničarsko društvo, 2003. Str. 43.

19 Nebesny, T.; M. Švob. Izgradnja knjižne zbirke u narodnim knjižnicama. [citirano: 2020-0505]. Dostupno na: http://dzs.ffzg.unizg.hr/text/nebesny_svob.htm.

20 Usp. Špiranec, S. Knjižnice. Nav. dj., str. 40.
} 
ne“, ${ }^{21}$ pa se tako ni samom činjenicom da knjižnični fondovi osiguravaju pristup velikom broju znanstveno utemeljene građe neće smanjiti utjecaj nevjerodostojne stručne građe na mišljenja i vjerovanja ljudi te na njihovo donošenje odluka. Stoga je važno da knjižnice upozoravaju korisnike na taj fenomen, da ih informacijski opismenjuju u svrhu vrednovanja informacija, ali i da same odgovorno kreiraju sve sadržaje koji čine kataložne zapise.

\section{Sadržajna obrada građe u narodnim knjižnicama: alati i moguć- nosti}

Sadržajnom obradom knjižnične građe utvrđuje se i opisuje sadržaj građe, što omogućuje njezin smještaj i pretraživanje prema sadržaju te izradu bibliografija. Sadržajna obrada uključuje dva osnovna načina prikazivanja sadržaja: klasifikaciju i predmetnu obradu. No jedan od oblika sadržajne obrade dokumenata jest i dokumentacijska ili informacijska obrada, koja može biti bibliografska, analitička i sintetička. ${ }^{22} \mathrm{U}$ ovom se radu, osim klasifikacije i predmetnog označivanja, sadržajna obrada nevjerodostojne stručne građe tematizira i s obzirom na analitičku obradu, odnosno izradu anotacija kojima knjižničari ukratko prikazuju sadržaj dokumenta.

\subsection{Klasifikacija}

U narodnim knjižnicama svih triju integriranih knjižničnih sustava čiji su mrežni katalozi pretraživani za potrebe ovoga rada (CROLIST, MetelWIN, ZaKi), za klasificiranje knjižnične građe koristi se Univerzalna decimalna klasifikacija (u daljnjem tekstu: UDK), jedna od najčešće upotrebljavanih općih knjižničnih klasifikacija u Europi.

Od svoga prvog izdanja (1905. godine) do danas, UDK je doživio više izdanja i prerada, potaknutih razvojem znanosti i tehnologije te društvenim promjenama.

Zahvaljujući svojoj strukturi, UDK nudi velik raspon mogućnosti za označivanje različitih sadržaja dokumenata unutar pojedine struke ili znanosti, no postavlja se pitanje može li se njime iskazati da je sadržaj dokumenta o kojemu je riječ znanstveno neutemeljen, metodološki nesustavan te da je rezultat autorovih dojmova, odnosno osobnih zaključaka o pojedinoj temi.

Takvi bi se dokumenti mogli pobliže označiti općim pomoćnim oznakama za odnose, dodavanje, svojstva i oblik te oznakama izvan UDK sustava.

\footnotetext{
21 Isto.

22 Usp. Tadić, K. Rad u knjižnici. Opatija: Naklada Benja, 1994. Str. 109.
} 
Primjerice, simbolom za odnos ${ }^{23}$, ,“ ili simbolom za dodavanje „,+“ mogle bi se oznake 001.94 Zabilježene pojave koje nisu u potpunosti razjašnjene ili 001.9 Širenje ideja kombinirati s drugim oznakama.

Također, postoje pomoćne oznake za fazne odnose, procese i postupke među kojima je i -042.1 Faza pristranosti, kojima se dodatno može iskazati vrsta odnosa između dviju UDK oznaka koje spaja simbol za odnos ,,:“. Primjenjuju se kao sufiks glavnom broju ,ako je aspekt procesa, aktivnosti ili postupka sekundaran u odnosu na predmet". ${ }^{24}$

No tim se pomoćnim oznakama pobliže označuje tema sadržaja dokumenta (,o čemu je sadržaj“), a ne i njegov oblik (,što je sadržaj“), zbog čega nisu najbolje rješenje, premda bi mogle poslužiti s obzirom na to da se u praksi katkad i glavne UDK oznake primjenjuju u označivanju oblika dokumenata. ${ }^{25}$

Dok se navedenim oznakama označava sadržaj dokumenta, pomoćnim oznakama za oblik (0...) može se, osim fizičkoga, označiti i unutarnji oblik dokumenta, odnosno način prikazivanja, definiran kao svojstvo da ,oblik dokumenta utječe na predmet““.

U bilješci o njihovoj primjeni spominje se mogućnost kreiranja oznaka kombiniranjem oznake (0:) s odgovarajućom glavnom UDK oznakom. Glavne oznake koje bi mogle poslužiti u kreiranju pomoćne oznake za unutarnji oblik nevjerodostojne stručne građe u kombinaciji s (0:) mogle bi biti sljedeće: 001.94 Zabilježene pojave koje nisu u potpunosti razjašnjene; $001.95 \mathrm{Na}$ mjerne znanstvene obmane i prijevare; 001.97 Pseudoznanstvena proricanja, predodžbe; 001.98 Falsificiranje znanosti, uključujući lažne doktrine, zablude (zbog nedovoljnog znanja, slijepog vjerovanja, prekomjernog fanatizma i sl.). Tako kreirana oznaka, koja bi se mogla dodati UDK oznaci koja označava sadržaj dokumenta (mogla bi stajati i ispred nje), glasila bi ovako: (0:001.94/.98), a mogla bi imati jedan od sljedećih opisa: Neprovjerene tvrdnje; Nevjerodostojne tvrdnje; Znanstveno neutemeljene tvrdnje; Neprovjereno; Nevjerodostojno. Primjerice, tako bi se mogle kreirati sljedeće oznake: (0:001.94/.98)159.9 Neprovjerene tvrdnje o psihologiji; 159.9(0:001.94/.98) Psihologija - neprovjereno; (0:001.94/.98):001.94 Neprovjerene tvrdnje o zabilježenim pojavama koje nisu u potpunosti razjašnjene.

Oznake izvan sustava UDK mogu se dodavati UDK oznakama korištenjem simbola „* koji oznaci dodaje riječ, simbol, broj ili „neautorizirane, lokalno

23 Brojčane oznake, nazivi stručnih UDK skupina, simboli, pomoćne oznake i njihovi opisi koji se navode u ovome poglavlju preuzeti su iz baze Hrvatski UDK Online. [citirano: 2020-05-05] Dostupno na: https://hr.udc-hub.com/hr/login.php.

24 Primjerice, 159.9-042.1:001.9 značilo bi ,pristrano širenje ideja u psihologiji“.

25 Primjerice, stripovi se označuju oznakom 741.5 Karikatura. Strip. Uključujući: Satirički i šaljivi crteži, kojom bi se imala označivati samo građa o stripu, a ne i sam strip, premda se on može izraziti pomoćnom oznakom za oblik stripa (0:741.52), npr. 929(0:741.52) Biografije u obliku stripa, kao što se navodi u bazi Hrvatski UDK online. 
označene bilješke koje mogu nalikovati UDK broju, ali nisu dio UDK sustava“. U ovom slučaju to bi mogla biti neka riječ ili kratica kojom se označuje nevjerodostojnost sadržaja dokumenata, primjerice: *nevjerodostojno; *neprovjereno; *NT - nevjerodostojne tvrdnje.

\subsection{Predmetno označivanje}

Za razliku od stručnog kataloga, u kojemu su djela razvrstana u klasifikacijske skupine i podskupine s obzirom na njihov sadržaj, a koji se temelji na međunarodno razvijanoj i prihvaćenoj klasifikaciji, za predmetni knjižnični katalog ne postoji jedinstven međunarodni sustav, a u hrvatskom narodnom knjižničarstvu ne postoji jedinstven sustav ni na nacionalnoj razini. ${ }^{26}$

Za hrvatske narodne knjižnice iznimno je važan „Pravilnik za predmetni kata$\log$ “ autorica Vujić i Štrbac, koncipiran kao praktični priručnik s opisom temeljnih načela za predmetnu obradu te razradom praktičnih postupaka i primjera analize sadržaja i predmetnog označivanja. ${ }^{27}$

U Pravilniku se navodi da je zadatak predmetnog kataloga „omogućiti pronalaženje literature o jednom određenom predmetu u knjižnici, a da prethodno nije potrebno znati ime autora, naslov dokumenta ili stručnu skupinu kojoj određeni dokument pripada. Svojim odrednicama [predmetni] katalog daje sažet iskaz o sadržaju i obliku dokumenta. “28 Što se tiče odabira dokumenata koji ulaze u predmetnu obradu, s obzirom na njihov sadržaj i vrstu, autorice navode da je opće „pravilo da predmetni katalog obuhvaća građu koja ima stručni i znanstveni karakter“, dok u njega ne ulaze „beletristika, izvorna filozofska djela, opće enciklopedije, leksikoni, dvojezični i višejezični rječnici i novine“". ${ }^{29}$

Prema Pravilniku, svrha je predmetne analize sadržaja dokumenta točno utvrditi njegov predmet ili temu. Predmetna odrednica ${ }^{30}$ oblikovani je predmetni niz koji se sastoji od jedne ili više predmetnih oznaka, kojim se izražava predmet sadržaja dokumenta ili dijela dokumenta.

\footnotetext{
26 Nacrt nacionalnog pravilnika u vlastitoj je nakladi objavila Mira Mikačić 1999. godine pod nazivom Pravilnik i priručnik za izradu predmetnog kataloga u knjižnicama Republike Hrvatske, no on nikada nije prerastao u nacionalno prihvaćen priručnik.

27 Štrbac, D.; M. Vujić. Pravilnik za predmetni katalog. Zagreb: Knjižnice grada Zagreba, 2004.

28 Isto, str. 15.

29 Isto, str. 16.

30 U predmetnom označivanju razlikuju se predmetne odrednice, ključne riječi i deskriptori. Ključna riječ definira se kao nenormirana riječ ili skupina riječi u prirodnom redoslijedu, a deskriptor kao normirana (tj. jednoznačno određena) riječ ili skupina riječi izabrana iz prirodnog jezika. Usp. Leščić, J. Klasifikacija i predmetno označivanje: priručnik za stručne ispite. Zagreb: Dominović, 2012. Str. 88.
} 
Iako predmetno označivanje obuhvaća i ključne riječi, odnosno nenormirane, slobodno oblikovane odrednice, zbog nepostojanja normativne kontrole ${ }^{31,32}$ koja bi omogućila postizanje dosljednosti u njihovu oblikovanju, u ovome se radu predmetna obrada tematizira samo u kontekstu predmetnih odrednica. Iako nepostojanje normativne kontrole omogućuje veću slobodu i fleksibilnost u oblikovanju ključnih riječi, ono smanjuje dosljednost, a smatra se da je upravo dosljednost u predmetnom označivanju ono što korisniku osigurava veću, a samim tim i bržu mogućnost pronalaska željenog dokumenta. ${ }^{33}$

Špiranec navodi da se koncepcije sadržajnog označivanja ugrubo mogu podijeliti u dvije skupine, tj. dvije krajnosti u pristupu indeksiranju - $\mathrm{u}$ jednoj, predmetni stručnjak polazi od dokumenta, a u drugoj od korisničkih potreba, odnosno mogućih informacijskih potreba. ${ }^{34}$

U novijim teorijskim razmatranjima koja se bave postupkom sadržajne analize i određivanjem predmeta nekog dokumenta te različitim koncepcijama i pristupima sadržajnom označivanju uvijek se ističu potrebe korisnika kao ključni cilj i svrha sadržajnog označivanja. Kritike koncepata tematike pri predmetnom označivanju odnose se na manjkavost pristupa dokumentima kao izoliranim izvorima znanja, odnosno umjesto usredotočenosti na sadržaj dokumenta, predmetni bi stručnjak trebao anticipirati utjecaj i vrijednost dokumenta za pretpostavljenog korisnika, promatrajući dokument $u$ kontekstu svih njegovih značenja, s gledišta autora, korisnika, u odnosu na ostale izvore i znanstvene spoznaje. ${ }^{35}$

U Pravilniku autorica Vujić i Štrbac navodi se da se radi jasnijeg određenja općih odrednica koriste dodatne oznake, koje mogu biti: tematske, zemljopisne, vremenske i formalne. Tematske dodatne oznake, uz oznake za opći pojam, izražavaju svojstvo ili osobinu; stanje; postanak, podrijetlo, ciljeve, uzroke i posljedice;

\footnotetext{
31 Kao što se navodi u priručniku „Univerzalna decimalna klasifikacija“, normativna kontrola i uspostava normativne datoteke predmetnih odrednica pridonose dosljednosti i ujednačenosti u predmetnom označivanju građe slične ili iste tematike uvijek istim predmetnim odrednicama. Na taj se način pri pretraživanju mrežnog kataloga povećava vjerojatnost dobivanja rezultata pretrage u kojima će biti prikazane sve jedinice građe relevantne za pretraživanu temu koje se nalaze u fondu knjižnice. Usp. Leščić, J. Univerzalna decimalna klasifikacija: priručnik za knjižničare i shema za narodne knjižnice. Zagreb: Dominović, 2012. Str. 12.

32 Budući da je općenito prihvaćeno mišljenje da je predmetno označivanje više subjektivan nego objektivan proces, normativna kontrola način je da ga se usmjeri prema neutralnosti, objektivnosti, nepristranosti i ujednačenosti/dosljednosti, osnovnim načelima ugrađenima u sustave za organizaciju znanja, kao i u smjernice u postupcima označivanja. Usp. Špiranec, S. Subjektivna paradigma sadržajnog označivanja. // Vjesnik bibliotekara Hrvatske 57, 1-3(2014), 1-14. Dostupno i na: http://hrcak.srce.hr/142161 [citirano: 2020-10-03].

33 Usp. Petr Balog, K.; I. Majlinger Tanocki. Dosljednost predmetnog označivanja elektroničke građe u mrežnim katalozima hrvatskih narodnih knjižnica. // Vjesnik bibliotekara Hrvatske 57, 1-3(2014), str. 69. Dostupno i na http://hrcak.srce.hr/142252 [citirano: 2020-10-03].

34 Špiranec, S. Subjektivna. Nav. dj., str. 7.

35 Isto, str. 5.
} 
povijest, razvoj ili budućnost; radnju, djelatnost i proces; ulogu, analizu, istraživanje, pristup, metodu, znanstveno ili neko posebno gledište te uporabu i primjenu. ${ }^{36}$

S obzirom na to, za predmetno označivanje nevjerodostojnih, znanstveno neutemeljenih dokumenata u hrvatskim narodnim knjižnicama mogla bi se iskoristiti mogućnost oblikovanja posebne tematske dodatne oznake iz kategorije oznaka kojima se izražava pristup, metoda, znanstveno ili neko posebno gledište. U Pravilniku se uz tu kategoriju navode neki od sljedećih primjera: analiza, duhovno gledište, filozofsko gledište, kršćansko gledište, moralno gledište, popularni pristup itd. ${ }^{37} \mathrm{Na}$ tragu tih rješenja bilo bi moguće oblikovati tematsku dodatnu oznaku koja bi glasila „osobno gledište“ i koja bi se dodavala nakon predmetne oznake kojom se predmeti sadržaj građe čiji autor nije znanstvenik ili stručnjak za pojedino znanstveno područje, a u kojoj on iznosi osobno gledište o jednoj ili više znanstvenih tema.

Navedene mogućnosti označivanja sadržaja koje nudi sustav UDK i predmetno označivanje pokazuju da je tim alatima sadržajne obrade moguće iskazivanje nevjerodostojnosti, odnosno znanstvene neutemeljenosti sadržaja dokumenta, no pretraživanjem mrežnih kataloga triju odabranih knjižničnih sustava autorice ovog rada nisu pronašle primjere korištenja tih mogućnosti u praksi. To se prije svega može povezati s tradicijom etičke odgovornosti knjižničarske struke, kojoj su među temeljnim etičkim načelima razvoj i očuvanje intelektualnih sloboda pojedinaca te objektivnost i neutralnost pri prosudbi. ${ }^{38}$ Označivanjem sadržaja pojedinog dokumenta kao sadržaja s ,neprovjerenim informacijama“, odnosno kao nevjerodostojnog, znanstveno neutemeljenog, ,pseudoznanstvenog“ sadržaja - te bi vrednote mogle biti dovedene u pitanje. Problemom razgraničenja (demarkacije) znanosti filozofi znanosti i epistemolozi bave se već stoljećima. ${ }^{39}$ Posljednjih desetljeća tema granice znanstvenog, neznanstvenog i pseudoznanstvenog dodatno je usložnjena. ${ }^{40}$

Ipak, sve veća vidljivost u virtualnom okruženju pred knjižničarsku struku stavlja novi izazov: pronaći način kako da se korisnicima daju informacije o nevjerodostojnosti sadržaja stručne građe, a da se pritom ne naruše spomenuta etička načela.

Pretraživanjem dostupnih izvora autorice nisu pronašle stručne informacije kojima se ta problematika tematizira iz knjižničarske perspektive vezano za sadržajnu obradu građe. U stručnoj se knjižničarskoj literaturi jedino naglašava objek-

36 Usp. Štrbac, D.; M. Vujić. Nav. dj., str. 119-124.

37 Isto.

38 Usp. Etički kodeks Hrvatskog knjižničarskog društva. [citirano: 2020-10-01]. Dostupno na: https://www.hkdrustvo.hr/hr/eticki_kodeks/.

39 Usp. Popper, K. R. Logika naučnog otkrića. Beograd: Nolit, 1973. Str. 67-72.

40 Usp. Science and pseudo-science. // Stanford Encyclopedia of Philosophy. [citirano: 2020-1001.] Dostupno na: https://plato.stanford.edu/entries/pseudo-science/. 
tivnost u pristupu. Primjerice, „Priručnik za oblikovanje predmetnih odrednica Kongresne knjižnice ${ }^{\text {"4t1 }}$ navodi da se odrednice ne dodjeljuju tako da se njima etiketira predmet ili izražava osobno vrednovanje sadržaja djela. Iako znanje i prosudba sadržajnog analitičara imaju presudnu ulogu u procjeni sadržaja djela, odrednica ne smije odražavati mišljenje ili stav sadržajnog analitičara prema sadržaju. Ako je moguće, pri odabiru odrednice treba slijediti iskazanu nakanu autora ili nakladnika s obzirom na čitateljsku publiku kojoj je djelo namijenjeno, tretman sadržaja kao činjenice ili fikcije i slično. ${ }^{42}$

S obzirom na svu složenost konteksta sadržajne obrade nevjerodostojne stručne građe, može se zaključiti da je knjižničar u tom poslu u procjepu između kriterija kojima je različito temeljno polazište: dokument, korisničke potrebe, poslanje knjižničarske struke, etički kodeks ili pak namjere autora i izdavača.

\subsection{Anotacije}

Anotacija je bilješka kojom se daje „objašnjenje bilo kojeg elementa bibliografskog opisa, ili pak elemenata sadržaja djela. Anotacija može proširiti bibliografsku obavijest (npr. o prethodnim izdanjima, materijalnom obliku ili fizičkom stanju dokumenta i sl.) ili opisati sadržaj, temu, predmet djela. Nema strogih pravila izrade, za razliku od apstrakta ili sažetka neobvezatna je, u pravilu kraća od njih.“43

Tadić je definira kao „kratak prikaz sadržaja primarnog dokumenta, iskazan opisno (deskriptivna anotacija) ili kritički. Kritička anotacija vrednuje primarni dokument. Anotacije ne smiju biti dulje od 400 do 600 slovnih znakova, ali mogu biti i vrlo kratke.“44

Za razliku od knjižničarskih anotacija, nakladnička anotacija ima svrhu oglašavanja koje bi čitatelja trebalo navesti na kupnju publikacije na temelju danih informacija. ${ }^{45}$

\footnotetext{
41 Najšire prihvaćen standard za predmetnu obradu u međunarodnoj knjižničarskoj zajednici. Usp. Predmetni sustav Nacionalne i sveučilišne knjižnice u Zagrebu. [citirano: 2020-04-20]. Dostupno na: http://ps.nsk.hr/o-predmetnom-sustavu/.

42 Prijevod je preuzet iz „Priručnika za predmetne odrednice“ za koji NSK preuzima, prilagođava i prevodi rješenja iz sustava LCSH. Usp. Pravilnik i priručnik za predmetne odrednice. Verzija 1. Zagreb: Nacionalna i sveučilišna knjižnica, 2019. Str. 23. [citirano: 2020-04-18]. Dostupno na: http://ps.nsk.hr/wp-content/uploads/2019/09/Pravilnik-i-priru\%C4\%8Dnik-za-predmetne-odrednice-srpanj-2019-v2.pdf.

43 Anotacija. // Hrvatska enciklopedija. [citirano: 2020-06-05]. Dostupno na: https://www.enciklopedija.hr/Natuknica.aspx?ID=2895.

44 Tadić, K. Nav. dj., str. 109.

45 Usp. Horvat, J.; P. Ljevak; N. Tomašević; D. Gavranović. Književna kritika, nakladničke i knjižničarske anotacije u modernim i tradicionalnim medijima. // Arhivi, knjižnice, muzeji: mogućnosti suradnje u okruženju globalne informacijske infrastrukture 17(2014), str. 76. Dostupno i na: https://hrcak.srce.hr/ojs/index.php/akm/article/view/3563 [citirano: 2020-06-06].
} 
Pretražujući anotacije u kataložnim zapisima dvaju mrežnih kataloga narodnih knjižnica, katalogu Gradske knjižnice Zadar i katalogu Knjižnica grada Zagreba, autorice Horvat, Ljevak, Tomašević i Gavranović navode da se u pretraživanim katalozima mogu prepoznati tri vrste anotacija: deskriptivna ili opisna anotacija, anotacija preuzeta iz recenzije ili prikaza djela te anotacija izrađena u svrhu preporuke za čitanje. ${ }^{46}$ Valja naglasiti da se uz anotaciju preuzetu iz recenzije ili prikaza djela preuzeti tekst navodi pod navodnim znakovima te se naznačuje izvor: recenzija, prikaz, predgovor, pogovor, korica knjige i druga informativna mjesta (npr. tekst se preuzima iz nakladničkih anotacija). ${ }^{47}$

Pretraživanjem mrežnih stranica narodnih knjižnica čiji su mrežni katalozi pregledavani za potrebe ovog rada, kao i pretraživanjem drugih dostupnih izvora, autorice ovog rada nisu pronašle obznanjene kriterije odabira građe za anotiranje niti kriterije oblikovanja anotacija.

Također, pretraživanjem kataloga hrvatskih narodnih knjižnica triju integriranih knjižničnih sustava, autorice nisu pronašle katalog u kojemu se u anotacijama pretraživanih primjera nevjerodostojne stručne građe naznačuje to njihovo obilježje, što je moguće učiniti i bez iskazivanja vrijednosnog suda o publikaciji. Ta se mogućnost prije svega odnosi na upotrebu izraza poput ,autor/autorica tvrdi/iznosi tezu/ mišljenje/osobno viđenje“, „, knjizi se navodi“ i slično, kao i na preciziranje čitalačke publike kojoj je anotirani naslov ponajprije namijenjen - umjesto „učenicima“, „studentima“, „stručnjacima“ ili „svima koji su zainteresirani za znanost“, takva će građa, primjerice, biti namijenjena „,̌itateljima koje zanima alternativa znanosti“.

\section{Obilježja nevjerodostojne stručne građe i praksa sadržajne obrade}

Prema Hrvatskoj enciklopediji, znanost je skup znanja dobivenih nekom od znanstvenih metoda te racionalna djelatnost predviđanja i objašnjenja pojava $u$ okolini (znanstveno znanje) koja se ostvaruje svođenjem pojedinih pojava pod univerzalne zakone..$^{48}$

Sedamdesetih je godina prošlog stoljeća povjesničar znanosti Thomas Kuhn u djelu „Struktura znanstvenih revolucija“ razradio tezu da razvoj znanosti nije kontinuiran proces, već proces obilježen nizom raskida i smjenom razdoblja „normalne znanosti“ i „revolucija“: rad znanstvene zajednice na artikulaciji i proširenju vladajuće znanstvene paradigme proizvodi anomalije, odnosno rezultate koji ne mogu biti objašnjeni parametrima vladajuće paradigme, što dovodi do krize, a razrješenje je krize u znanstvenoj revoluciji kojom se uspostavlja nova paradigma. ${ }^{49}$

46 Isto. str. 86.

47 Isto.

48 Usp. Znanost. // Hrvatska enciklopedija. [citirano: 2020-06-20]. Dostupno na: https://www. enciklopedija.hr/Natuknica.aspx?ID=67353.

49 Usp. Kuhn, T. S. Struktura znanstvenih revolucija. Zagreb: Naklada Jesenski i Turk: Hrvatsko sociološko društvo, 1999. Str. 232. 
Pritom je važno naglasiti da se profesionalna tradicija teorija, metoda i kompetencija stječe obrazovanjem unutar postojeće paradigme te da samo istraživanja čvrsto ukorijenjena u suvremenu znanstvenu tradiciju mogu razbiti tu tradiciju i dovesti do nastanka nove. ${ }^{50}$

Premda formalno obrazovanje autora ne može biti kriterij razlikovanja znanosti i pseudoznanosti, autorove profesionalne kompetencije mogu uputiti na njegovu stručnost i vjerodostojnost - treća od osam uputa na IFLA-inoj infografici „Kako prepoznati lažne vijesti“ glasi: „Provjeri autora“. ${ }^{51}$ Nijedan od autora čije su publikacije odabrane kao primjeri za potrebe ovog rada nema zvanje stečeno formalnim obrazovanjem iz područja kojim se bavi u publikaciji, kao ni iz njemu srodnog područja. Radi potkrjepe, u tablice sa zbirnim prikazom podataka iz kataložnih zapisa pretraživanih publikacija uvršten je i redak s profesijom autora. (vidi tablicu 2, 3, 4, 5 i 6).

Za razliku od znanosti, „pseudoznanost“ se određuje kao neznanost koja se pretvara da je znanost, odnosno riječ je o sustavu vjerovanja, tvrdnji ili teorija koje tvrde da su znanost, ali do kojih se nije došlo znanstvenim putem..$^{52}$

\subsection{Obilježja nevjerodostojne stručne građe}

Ovisno o kriterijima razgraničenja znanstvenih od pseudoznanstvenih diskursa koje pojedini autori izdvajaju, postoje različiti popisi obilježja tekstova neutemeljenih u znanosti, a obično sadržavaju od pet do deset obilježja. ${ }^{53} \mathrm{Za}$ potrebe ovoga rada izdvojena su sljedeća obilježja takvih djela: temelje se na teorijama koje su statične, koje nisu nastale dugom evolucijom, već proizlaze iz autoriteta ili neponovljivog eksperimenta; naglasak je eksperimenata na pokušaju potvrđivanja teorije, a ne opovrgavanju (biraju se „dokazi“ koji idu u prilog nekoj tvrdnji, a zanemaruju se oni koji tvrdnju ne podupiru); ne nude međurezultate, već samo konačni rezultat; rezultati istraživanja ne objavljuju se u znanstvenim časopisima i kritika se doživljava kao napad ili urota; ne uklapaju se u postojeću znanstvenu paradigmu - često dolaze u sukob s čvrstim prirodnim zakonima (npr. zakonom očuvanja energije); koriste se nepreciznom i(li) netočnom terminologijom. ${ }^{54}$

\footnotetext{
50 Isto. str. 153-167.

51 IFLA. How to spot fake news. [citirano: 2020-09-28]. Dostupno na: https://www.ifla.org/ publications/node/11174.

52 Usp. Pseudo-science. // Cambridge English Dictionary. [citirano: 2020-06-20]. Dostupno na: https://dictionary.cambridge.org/dictionary/english/pseudo-science.

53 Usp. Hansson, S. O. Defining science and pseudoscience. // Philosophy of pseudoscience: reconsidering the demarcation problem / ed. by Massimo Pigliucci and Maarten Boudry. Chicago and London: The University of Chicago Press, 2013. Str. 61-77. Dostupno i na: https://books.google.hr/books?id=Pc4OAAAAQBAJ\&lpg=PA61\&ots=wZFOsuv_Du\&d [citirano: 2020-10-01].

54 Usp. Rončević, I. Prepoznavanje pseudoznanstvenih tvrdnji. // Ideje.hr. [citirano: 2020-1001]. Dostupno na: http://ideje.hr/prepoznavanje-pseudoznanstvenih-tvrdnji.
} 
Navedena obilježja prepoznatljiva su u sadržaju svih pet publikacija koje su odabrane za potrebe ovog rada: „Biti i imati: promjenom vibracije do financijske slobode“; „Znanstveno - potpuno objašnjenje čovjeka: sreća, stres, osjećaji i razum“; „Prizma Lyre: istraživanje ljudskog galaktičkog podrijetla“; „Zbogom cjepiva: štetna i neučinkovita“; ,Maleni ispod zvijezda: knjiga o znanstvenim obmanama“, ali se u tablici s primjerima obilježja znanstveno neutemeljenog diskursa, radi sažetijeg prikaza, svako od tih obilježja ne argumentira primjerima iz svih pet publikacija, već ih je izdvojeno nekoliko (vidi tablicu 1).

\section{Tablica 1. Primjeri obilježja znanstveno neutemeljenog diskursa}

Autor svoja istraživanja ne ukorjenjuje u suvremenoj znanstvenoj tradiciji pripadajućeg područja i izložena se teorija ne uklapa u postojeću znanstvenu paradigmu.

Zdravko Vampovac u knjizi „Maleni ispod zvijezda“ tvrdi da njegova knjiga „ne prihvaća NJIHOVU ${ }^{55}$ suspektnu znanost, nego ima svoj vlastiti pogled na svijet i na sve ono što čovjeka okružuje i zanima. " ${ }^{56}$ Pojmom „oni“ autor obuhvaća: „uvjerene ateiste”, „pristalice evolucionističkih teorija“, „pobornike heliocentričnog sustava“, „profesore i doktore prirodnih znanosti stečenih na masonskim koledžima i sveučilištima, posebno onim engleskim ili američkim poput: (...) Princeton University, Massachusetts Institute of Technology, Yale University, Harvard University (...) Cambridge, Oxford (...). ${ }^{\text {"57 }}$

U knjizi „Znanstveno - potpuno objašnjenje čovjeka“ autor Branko Pepeljnjak teze i zaključke o emocijama niže u obliku osobnih impresija te metodom uopćavanja bez potkrjepe bibliografskim izvorima, rezultatima istraživanja ili drugim dokazima. Na primjer:

„Kao osnovno, čovjeku nije problem da nađe činjenice i kada su one potpuno nevidljive, kada nisu očite! Na primjeru sreće, sve činjenice su vidljive i očite - čovjek ima upravo sve činjenice pred samim sobom! Štoviše - on ih sam stvara! Dakle - čovjek potpuno sam stvara i ostvaruje svoju sreću! Upravo sve što čini, i upravo u svakom trenutku - čovjek čini za sreću, zbog sreće, odnosno, stvara sebi sreću! No, unatoč tome - čovjek ne zna, zapravo, ništa o sreći (koliko god mu se činilo da nešto zna)! ${ }^{\text {‘5 }}$

\footnotetext{
55 Isticanje autorovo.

56 Vampovac, Z. Maleni ispod zvijezda: knjiga o znanstvenim obmanama. Vodice: vlast. nakl., 2018. Str. 16.

57 Isto, str. 15.

58 Pepeljnjak, B. Znanstveno - potpuno objašnjenje čovjeka: sreća, stres, osjećaji i razum. Zagreb: vlast. nakl., 2018. Str. 3.
} 
U knjizi „Zbogom cjepiva“ autor Darko Vujnović svoje tvrdnje potkrjepljuje različitim izvorima, istraživanjima i njihovim rezultatima, pri čemu su mnogi izvori s Facebooka ili Wikipedije. Navodi i velik broj referenci s kraja 19. stoljeća, odnosno početka 20. stoljeća, ali samo za pojedine od njih navodi da su iz tog razdoblja. ${ }^{59}$ Tvrdi da istraživanja o korisnosti cjepiva nema, da se „zaobilaze u širokom luku“ ${ }^{\text {"60 }}$ „iz jednostavnog razloga što bi takva istraživanja dokazala kako cjepiva nisu učinkovita “61. U istoj publikaciji cijelo jedno poglavlje bavi se argumentacijom teze da virusi i ne postoje. ${ }^{62}$

Sa suvremenom znanstvenom paradigmom u suprotnosti je teza autorice Ane Bučević u knjizi „Biti i imati“ da je novac energija: „Novac je dio duhovnosti“ ${ }^{63}$ „Duhovnjak u novcu ne vidi ništa loše. Znajući da je energija on radi zamjenu“ ${ }^{\prime \prime 4}$, „Vi želite osjećati energiju koju vam novac daje. Energiju slobode. Energiju obilja. ${ }^{\text {"65 }}$

Izložene su teorije statične, nisu nastale dugom evolucijom, već proizlaze iz autoriteta ili neponovljivog eksperimenta.

U predgovoru knjige „Prizma Lyre“ Lysse Royal i Keitha Priesta navodi se sljedeće: „Prvi dio knjige sadrži originalni materijal Prizme Lyre, bez ikakvih izmjena. Budući da je materijal diktirala višedimenzionalna svijest imenom Germane, koju je 1989. kanalizirala Lyssa Royal Holt, nismo htjeli ništa mijenjati. Drugi dio ove knjige je transkript, prijepis radionice Lysse koja je kanalizirala Germanea 1999. godine." ${ }^{\text {66 }}$

\footnotetext{
59 Poveznice prema referencama u knjizi navedene su i na mrežnim stranicama nakladnika Omega lan. Usp. Vujnović-linkovi. // Omega lan.[citirano: 2020-08-05]. Dostupno na: https://www. omegalan.info/vujnovic-linkovi/.

60 Vujnović, D. Zbogom cjepiva: štetna i neučinkovita. Zagreb: Omega lan, 2018. Str. 72.

61 Isto, str. 78.

62 Usp. Isto, str. 37-42.

63 Bučević, A. Biti i imati: promjenom vibracije do financijske slobode. Split: Kontakt plus, 2018. Str. 11.

64 Isto, str. 17.

65 Isto, str. 25.

66 Royal, L.; K. Priest. Prizma Lyre: istraživanje ljudskog galaktičkog podrijetla. Bregana: Harša, 2018. Str. 7.
} 
Dovodeći u pitanje praksu citiranja i stavljanja fusnota, autor Zdravko Vampovac u knjizi „Maleni ispod zvijezda“ ustvrđuje sljedeće:

„...odakle uzeti citat ili pripisati kakvu fusnotu uz tvrdnje da su prije velikog potopa diljem Zemlje rasla stabla, pače i čitave šume različitih vrsta mega drveća čija je visina dosezala i do fantastičnih 100 kilometara? (...) Nema takve knjige, nema literature i zasada nema te stručne osobe koja bi stala u obranu ovih tvrdnji. ${ }^{\text {" } 7}$

Naglasak je diskursa na pokušaju potvrđivanja teorije, a ne opovrgavanju (biraju se „dokazi“ koji idu u prilog tvrdnji, a zanemaruju se oni koji tvrdnju ne podupiru). Autor ne nudi međurezultate, već samo konačni rezultat.

U knjizi „Biti i imati“ autorica Ana Bučević izdvaja situaciju u kojoj je svaki dan odlazila do bankomata premda na računu nije imala „ni eura“ i premda joj je „logika govorila da to ne radi“" ${ }^{\text {“68 }}$, ali novac se jedan dan iznenada pojavio. Premda u nastavku teksta autorica navodi da se ispostavilo da je riječ o odobrenom minusu, njezin je zaključak da je taj novac sama stvorila „spoznajom kreiranja“.69

Tvrdnju da je kamenje moglo rasti, autor knjige „Maleni ispod zvijezda“ potkrjepljuje usporedbom fotografija panjeva i fotografija „kamenih megapanjeva“, pri čemu ispod jedne od fotografija navodi:

„Godovi' u kamenu na umjetno odrezanoj planini. (Očit dokaz da je taj kameni div nekada bio živi organizam koji je rastao). ${ }^{\text {“70 }}$

Rezultati istraživanja ne objavljuju se u znanstvenim časopisima, a rukopisi ne prolaze stručnu recenziju.

Ni u jednoj publikaciji ne navode se prethodni objavljeni autorovi radovi iz tog ili srodnog područja u znanstvenim časopisima i nijedna publikacija ne sadržava stručnu recenziju.

\footnotetext{
67 Vampovac, Z. Nav. dj., str. 38.

68 Bučević, A. Nav. dj., str. 46.

69 Isto

70 Vampovac, Z. Nav. dj., str. 38.
} 
Autori se koriste nepreciznom i(li) netočnom terminologijom.

Već sam naslov i podnaslov publikacije „Znanstveno - potpuno objašnjenje čovjeka: sreća, stres, osjećaji i razum" upućuju na neprecizno korištenje standardnim književnim jezikom te psihologijskom terminologijom, pri čemu nisu uvaženi ni hijerarhijski odnosi među pojmovima.

Autorica Ana Bučević ne definira neke od ključnih pojmova kojima se koristi u knjizi „Biti i imati“ - „vortex“ $i$ „vibracije“.

I na koncu, četiri od navedenih pet publikacija objavljene su u vlastitoj nakladi ili u izdanju nakladničke kuće koja je u osobnom ili obiteljskom vlasništvu autora.

\subsection{Primjeri prakse sadrăajne obrade nevjerodostojne stručne građe}

Kataložni zapisi tih pet publikacija pretraživani su u skupnim mrežnim katalozima triju integriranih knjižničnih sustava, CROLIST-u, MetelWIN-u i ZaKi-u, prema sljedećim kriterijima: predmetnoj odrednici, klasifikacijskoj oznaci, anotaciji te varijanti prve razine signature. Prva razina signature izdvojena je zbog toga što se ona u narodnim knjižnicama oblikuje prema klasifikacijskoj oznaci te određuje smještaj građe na polici. Korisnicima je smještaj pojedine jedinice građe u slobodnom pristupu izvor informacija o struci kojoj pojedina publikacija pripada, o čemu govori i citat znanstvenika naveden na početku rada. Pretraživanje je provedeno od 20. do 30. rujna 2019. godine. Rezultati pretraživanja prikazani su u pet tablica, pri čemu se svaka od njih odnosi na jednu od pet odabranih publikacija. Rezultati u tablicama prikazani su zbirno, bez navođenja izvora, a zbog većeg broja sličnih rezultata u pojedinim je kategorijama naveden suženi izbor podataka. Samo su podaci o profesiji autora preuzeti iz mrežnog kataloga sustava $\mathrm{ZaKi}^{71}$ jer se jedino u njemu navode.

U pojedinim katalozima uz brojčane oznake UDK-a ne navode se nazivi stručnih UDK skupina i zato je u tablice, radi bolje preglednosti, u uglatim zagradama dodan njihov naziv, preuzet iz baze Hrvatski UDK Online.

${ }^{71}$ Podaci su preuzeti iz napomene u preglednim zapisima autorske odrednice. 
Prvi primjer: Bučević, Ana. Biti i imati: promjenom vibracije do financijske slobode. Split: Kontakt plus, 2018.

Tablica 2. Zbirni prikaz podataka iz kataložnih zapisa publikacije „Biti i imati“

\begin{tabular}{|c|c|}
\hline Naslov i autor(i) & Biti i imati : promjenom vibracije do financijske slobode / Ana Bučević \\
\hline $\begin{array}{l}\text { Napomena iz } \\
\text { preglednog zapisa } \\
\text { autorske odrednice }\end{array}$ & Profesorica kineziologije \\
\hline $\begin{array}{l}\text { Varijante } \\
\text { predmetnih } \\
\text { odrednica }\end{array}$ & $\begin{array}{l}\text { Trening asertivnosti - priručnici } \\
\text { Novac - psihološko gledište }\end{array}$ \\
\hline $\begin{array}{l}\text { Varijante } \\
\text { klasifikacijskih } \\
\text { oznaka }\end{array}$ & $\begin{array}{ll}\mathbf{1 5 9 . 9} & \text { Psihologija } \\
\mathbf{1 5 9 . 9 1 3} & \text { Mentalno zdravlje } \\
\mathbf{1 5 9 . 9 1 3 ( 0 3 5 )} & \text { [Mentalno zdravlje (priručnici)] } \\
\mathbf{3 3 6} & \text { Financije. Uključujući: Javne financije. Bankarstvo. Novac }\end{array}$ \\
\hline & $\begin{array}{l}\text { Premda je uobičajeno shvaćanje da su duhovnost i novac potpune suprotnosti, autorica ističe da je novac dio } \\
\text { duhovnosti - ako se vodi računa o redoslijedu: "imati" je nagrada za "biti". Novac ne donosi sreću, no onaj tko } \\
\text { prvo nauči biti sretan bez novca, s novcem može biti još sretniji. Ako si nesretan, nećeš biti sretan ni s novcem. }\end{array}$ \\
\hline Varijante anotacija & $\begin{array}{l}\text { Ovo nije obična knjiga o novcu, ovo je neobična knjiga o novcu. Ovo je duhovna knjiga o novcu, jer novac i jest } \\
\text { dio duhovnosti. Samo su nas uvjerili da nije. Uvjerili su nas da ga ne smijemo željeti ili imati. Ova knjiga pomoći } \\
\text { će vam da shvatite da to nije tako. Da smo došli kao duhovna bića u materijalni svijet da bismo živjeli balans } \\
\text { duhovnog i materijalnog. Ali da je prvo poanta BITI pa možeš živjeti svu ljepotu u IMATI. } \\
\text { IMATI će biti vaša nagrada za BITI. Ovo je knjiga koja će osvijestiti vaše negativne programe o novcu, koja će vam } \\
\text { pomoći da promijenite uvjerenja koja vam ne služe, koja će vas uputiti u metode kojima ćete mijenjati svoju } \\
\text { vibraciju prema novcu i koja će postati vaš suputnik u praksi na putu ostvarenja financijske slobode. Budite } \\
\text { uzbuđeni, jer povjerujete li onome što ovdje pročitate i budete li dosljedni u praktičnoj primjeni naučenog, } \\
\text { financijsko obilje i sloboda postat će dio vaše realnosti. A sloboda je najveći dar koji možete darovati sebi. }\end{array}$ \\
\hline $\begin{array}{l}\text { Varijante prve } \\
\text { razine signature }\end{array}$ & $\begin{array}{ll}159.9 & 613 \\
159.91 & 613.8 \\
159.913 & \end{array}$ \\
\hline
\end{tabular}

Jedna od predmetnih odrednica dodijeljenih ovom naslovu jest $\mathrm{i}$,novac - psihološko gledište“, a dodijeljene klasifikacijske oznake odnose se na mentalno zdravlje i na financije, uključujući javne financije, bankarstvo i novac (vidi tablicu 2).

U tablici su izdvojene anotacije iz dvaju mrežnih kataloga, pri čemu jednu od njih čini prepisan čitav tekst s korica publikacije, neoznačen kao citat i bez navoda izvora. U objema anotacijama navodi se da je knjiga posvećena povezanosti novca i duhovnosti te da je za stjecanje financijskog obilja dovoljno povjerovati savjetima iznesenima u knjizi, što je u skladu s načinom oblikovanja nakladničke, ali ne i knjižničarske anotacije.

Stručnu oznaku 159.9, navedenu na prvoj razini signature, pa tako i smještaj u slobodnom pristupu, ova knjiga, primjerice, dijeli s udžbenikom „Temelji psihologije" 72 , a oznaku 613.8, također s prve razine signature, s naslovom „Ovisnosti: prevencija, liječenje i oporavak"73, čiji je autor psihijatar.

Klasifikacijsku oznaku 336 Financije. Uključujući: Javne financije. Bankarstvo. Novac knjiga „Biti i imati“ dijeli s udžbenikom „Financijsko modelira-

72 Rathus, S. A. Temelji psihologije. Prijevod 5. izd. [izvornika]. Jastrebarsko: Naklada Slap, 2001.

73 Zoričić, Z. Ovisnosti: prevencija, liječenje i oporavak. Zagreb: Školska knjiga, 2018. 
nje" ${ }^{74}$ i s priručnikom „Blagajničko poslovanje i fiskalizacija”, ${ }^{75}$ čiji su autori matematičari ili ekonomisti.

Drugi primjer: Pepeljnjak, Branko. Znanstveno-potpuno objašnjenje čovjeka: sreća, stres, osjećaji i razum. Zagreb: vlast. nakl., 2018. ${ }^{76}$

Tablica 3. Zbirni prikaz podataka iz kataložnih zapisa publikacije „Znanstveno potpuno objašnjenje čovjeka“"

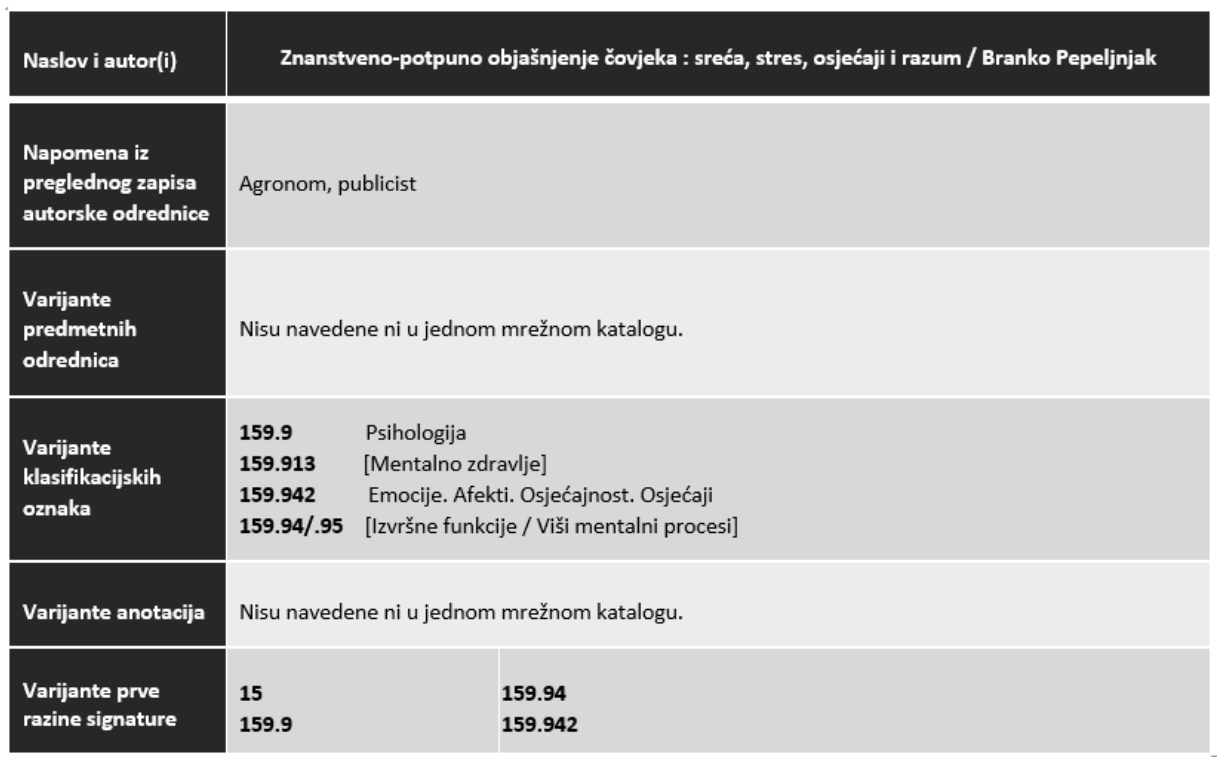

Predmetne odrednice za ovaj naslov nisu navedene ni u jednom mrežnom katalogu. Dodijeljene klasifikacijske oznake odnose se na psihologiju i obuhvaćaju raspon od mentalnog zdravlja do emocija, afekata, osjećajnosti i osjećaja te izvršnih funkcija ili viših mentalnih procesa (vidi tablicu 3). Ni u jednom mrežnom katalogu ne navodi se anotacija.

Klasifikacijsku oznaku 159.942 Emocije. Afekti. Osjećajnost. Osjećaji ova knjiga, primjerice, dijeli s naslovom „Emocionalna inteligencija“77 američkog psihologa i autora nekoliko nagrađivanih publikacija iz područja psihologije Daniela Gole-

74 Aljinović, Z.; B. Marasović; B. Šego. Financijsko modeliranje. 2. izmijenjeno i dopunjeno izd. Split: Ekonomski fakultet Split Sveučilišta, 2011.

75 Cirkveni, T.; N. Dremel; Š. Guzić; K. Horvat Jurjec; Đ. Jurić; Lj. Markota; Z. Trcović i suradnici. Blagajničko poslovanje i fiskalizacija. [2. izd.]. Zagreb: RRiF plus, 2013.

76 U kataložnim zapisima svih pretraživanih mrežnih kataloga naslov publikacije pogrešno je naveden, sa spojnicom (,znanstveno-potpuno“ / „znanstveno - potpuno“) umjesto s crticom, kako je na publikaciji („znanstveno - potpuno“), pri čemu su obje varijante jezično nevaljale.

77 Goleman, D. Emocionalna inteligencija: zašto može biti važnija od kvocijenta inteligencije. [9. izd.]. Zagreb: Mozaik knjiga, 2017. 
mana, a stručnu oznaku 159.94 s prve razine signature, kao i mjesto u slobodnom pristupu, sa stručnom publikacijom „Može li se oprostiti nakon rata: psihologijski pogled“"78 zbornikom radova studenata i nastavnika Odsjeka za psihologiju FFZG-a.

\section{Treći primjer: Royal, Lyssa; Keith Priest. Prizma Lyre: istraživanje ljudskog} galaktičkog podrijetla. Bregana: Harša, 2018. ${ }^{79}$

Tablica 4. Zbirni prikaz podataka iz kataložnih zapisa publikacije „Prizma Lyre“

\begin{tabular}{|c|c|}
\hline Naslov i autor(i) & Prizma Lyre : istraživanje ljudskog galaktičkog podrijetla / Lyssa Royal ; Keith Priest \\
\hline $\begin{array}{l}\text { Napomena iz } \\
\text { preglednog zapisa } \\
\text { autorske odrednice }\end{array}$ & $\begin{array}{l}\text { Lyssa Royal: američka psihologinja, "kanal" i predavač na temu izvanzemaljskih fenomena, učiteljica joge } \\
\text { Keith Priest: autorska odrednica za ovog autora ne navodi se u mrežnom katalogu }\end{array}$ \\
\hline $\begin{array}{l}\text { Varijante } \\
\text { predmetnih } \\
\text { odrednica }\end{array}$ & $\begin{array}{l}\text { Civilizacija - izvanzemaljski utjecaji } \\
\text { Izvanzemaljci - znanstveno-popularni prikaz } \\
\text { Vanzemaljci - znanstveno-popularni prikaz }\end{array}$ \\
\hline $\begin{array}{l}\text { Varijante } \\
\text { klasifikacijskih } \\
\text { oznaka }\end{array}$ & $\begin{array}{ll}001 & \text { Znanost i znanje općenito } \\
\mathbf{0 0 1 . 9} & \text { Šrenje znanosti. Popularizacija. Znanst.fant. } \\
\mathbf{0 0 1 . 9 4} & \text { Zabilježene pojave koje nisu u potpunosti razjašnjene } \\
\mathbf{0 0 1 . 9 4} & \text { Prikazi neobjašnjivih pojava }\end{array}$ \\
\hline & $\begin{array}{l}\text { Knjiga predstavlja komplilaciju godina uvida, deduktivnog rasuđivanja i kanaliziranja na temu ljudskog } \\
\text { galaktičkog podrijetla. Prate se različite izvnazemaljske rase (Liberanci, Veganci, Plejadanci, Orionci...), njihova } \\
\text { evolucija i povezanost sa Zemljom. Autori su proučavali mnogobrojna antroploška i metafizička djela i različite } \\
\text { kanale, ali većinom su koristili kanalizirane poruke koje je koautorica Lyssa Royal dobila od višedimenzionalne } \\
\text { svijesti pod imenom Germane. }\end{array}$ \\
\hline Varijante anotacija & $\begin{array}{l}\text { Prizma Lyre Istraživanje ljudskog galaktičkog podrijetla je knjiga koja istražuje ideju kreacije u drugačijem } \\
\text { svjetlu. Suprotno ideji da su ljudi rezultat kreacije, ona istražuje ideju da je kolektivna ljudska svijest (duša) } \\
\text { stvorila naš univerzum iz određenih razloga. Koji su to razlozi? Tko sve sudjeluje u tome? } \\
\text { U ovoj knjizi se nalaze odgovori na ta pitanja, što dovodi do zapanjujućih mogućnosti. Prizma Lyre prati različite } \\
\text { izvanzemaljske rase (Lyrance, Vegance, Plejadance, Orionce, Zeta Retikulance i druge) kroz njihovu evoluciju i } \\
\text { objašnjava njihovu povezanost sa Zemljom. Svugdje se naglašava naša galaktička međupovezanost i naša } \\
\text { zajednička želja za povratkom kući. }\end{array}$ \\
\hline $\begin{array}{l}\text { Varijante prve } \\
\text { razine signature }\end{array}$ & $\begin{array}{l}001.9 \\
001.94\end{array}$ \\
\hline
\end{tabular}

Obje navedene anotacije oblikovane su poput nakladničkih, a ne knjižničarskih anotacija, pri čemu jedna od njih sadržava tekst s korica publikacije, neobilježen kao citat i bez navedenog izvora.

U jednoj od njih se, bez ikakvih ograda, navodi da je sadržaj knjige „kompilacija godina uvida, deduktivnog rasuđivanja i kanaliziranja na temu ljudskog galaktičkog podrijetla“" (vidi tablicu 4).

78 Može li se oprostiti nakon rata: psihologijski pogled // 25. Ljetna psihologijska škola studenata i nastavnika Odsjeka za psihologiju Filozofskog fakulteta u Zagrebu / urednici Čorkalo Biruški, D.; D. Ajduković; A. Löw; H. Bakić. Zagreb: Filozofski fakultet Sveučilišta u Zagrebu: FF press, 2016. Str. 1-144. 79 Na slici su označene jezične pogreške, preuzete iz kataložnih zapisa te publikacije (isticanja autorica članka). 
Klasifikacijsku oznaku 001 Znanost $i$ znanje općenito, ova publikacija dijeli, primjerice, s naslovima kao što su „Točna boja neba: razmišljanja o znanosti u 21. stoljeću“"80 znanstvenika Igora Rudana, ili s naslovom „Uvod u filozofiju znanosti“"81 profesora filozofije Anthonyja O’Heara.

Stručne oznake s prve razine signature, pa tako i mjesto u slobodnom pristupu, publikacija dijeli s knjigom „Blesimetar Drugi: šest godina stariji, nimalo pametniji“'82 fizičara i popularizatora znanosti Saše Cecija.

Četvrti primjer: Vujnović, Darko. Zbogom cjepiva: štetna i neučinkovita. Zagreb: Omega Ian, 2018.

Tablica 5. Zbirni prikaz podataka iz kataložnih zapisa publikacije „Zbogom cjepiva“

\begin{tabular}{|c|c|c|}
\hline Naslov i autor(i) & & Zbogom cjepiva : štetna i neučinkovita / Darko Vujnović \\
\hline $\begin{array}{l}\text { Napomena iz } \\
\text { preglednog zapisa } \\
\text { autorske odrednice }\end{array}$ & \multicolumn{2}{|c|}{ Dipl. ing. elektrotehnike i prevoditelj } \\
\hline $\begin{array}{l}\text { Varijante } \\
\text { predmetnih } \\
\text { odrednica }\end{array}$ & \multicolumn{2}{|c|}{$\begin{array}{l}\text { Cjepiva - nuspojave } \\
\text { Prava pacijenata }\end{array}$} \\
\hline $\begin{array}{l}\text { Varijante } \\
\text { klasifikacijskih } \\
\text { oznaka }\end{array}$ & $\begin{array}{l}61 \\
614 \\
614.4 \\
615 \\
615.3 \\
615.3 \\
615.37 \\
615.37 \\
616 \\
616-035.7\end{array}$ & $\begin{array}{l}\text { Medicina } \\
\text { [Javno zdravstvo i higijena. Prevencija nesreća] } \\
\text { [Prevencija i kontrola zaraznih / prenosivih bolesti. Prevencija epidemije] } \\
\text { Farmakologija. Terapeutika. Toksikologija } \\
\text { Lijekovi prema porijeklu } \\
\text { Farmacija } \\
\text { [Imunoterapija] } \\
\text { Farmacija } \\
\text { [Patologija. Klinička medicina] } \\
\text { [Pogreške. Predrasude, uključujući: Pogrešne dijagnoze, pogrešne tehnike liječenja] }\end{array}$ \\
\hline Varijante anotacija & \multicolumn{2}{|c|}{$\begin{array}{l}\text { Autor knjige je tijekom svog profesionalnog rada prikupio veći broj saznanja i dokaza da učinkovito } \\
\text { (pravilno) liječenje nužno sadržava barem jednu komponentu detoksikacije tijela. Potom se logički } \\
\text { postavilo pitanje zašto današnja medicina, radi sprječavanja bolesti, toliko nade polaže u cjepiva? }\end{array}$} \\
\hline $\begin{array}{l}\text { Varijante prve } \\
\text { razine signature }\end{array}$ & $\begin{array}{l}61 \\
614\end{array}$ & $\begin{array}{l}615 \\
615.8\end{array}$ \\
\hline
\end{tabular}

U anotaciji se navodi da je autor do spoznaja o štetnosti i neučinkovitosti cjepiva opisanih u knjizi došao „tijekom svog profesionalnog rada“, iako se nigdje ne spominju njegovo medicinsko obrazovanje i iskustvo (vidi tablicu 5). Navedeni izraz, naime, prepisan je s korica publikacije, pri čemu to nije navedeno niti je izraz oblikovan kao citat.

80 Rudan, I. Točna boja neba: razmišljanja o znanosti u 21. stoljeću. Zagreb: Naklada Ljevak, 2017.

81 O’Hear, A. Uvod u filozofiju znanosti. Zagreb: Hrvatski studiji, 2007.

${ }^{82}$ Ceci, S. Blesimetar Drugi: šest godina stariji, nimalo pametniji. Zagreb: In.Tri, 2019. 
Dodijeljenu klasifikacijsku oznaku 615.3 Lijekovi prema porijeklu, izvoru, ova publikacija dijeli s priručnikom kao što je „Cijepljenje i cjepiva”, , čija je autorica pedijatrica, a klasifikacijsku oznaku 616 Patologija, klinička medicina, s knjigom „Bolja medicina: kako do djelotvornosti“‘84, čiji je autor liječnik, kirurg i publicist.

S obzirom na stručnu oznaku 615, s prve razine signature, u slobodnom bi pristupu ova knjiga stajala uz naslove kao što su „Nestali mikrobi: kako prekomjerna uporaba antibiotika potiče moderne pošasti“ ${ }^{\text {“85 }}$ američkoga liječnika, mikrobiologa i imunologa Martina J. Blasera te „Farmakoterapijski priručnik“"86, koji je specijalist kliničke farmakologije i interne medicine Božidar Vrhovac napisao sa suradnicima.

Peti primjer: Vampovac, Zdravko. Maleni ispod zvijezda: knjiga o znanstvenim obmanama. Vodice: vlast. nakl., 2018. ${ }^{87}$

Tablica 6. Zbirni prikaz podataka iz kataložnih zapisa publikacije „Maleni ispod zvijezda“"

\begin{tabular}{|c|c|}
\hline Naslov i autor(i) & Maleni ispod zvijezda / Zdravko Vampovac \\
\hline $\begin{array}{l}\text { Napomena iz } \\
\text { preglednog zapisa } \\
\text { autorske odrednice }\end{array}$ & Građevinski tehničar i publicist \\
\hline $\begin{array}{l}\text { Varijante } \\
\text { predmetnih } \\
\text { odrednica }\end{array}$ & $\begin{array}{l}\text { Znanost - kritike } \\
\text { Znanstvene zagonetke } \\
\text { Znanstvene obmane }\end{array}$ \\
\hline $\begin{array}{l}\text { Varijante } \\
\text { klasifikacijskih } \\
\text { oznaka }\end{array}$ & $\begin{array}{ll}001 & \text { Znanost i znanje općenito } \\
\mathbf{0 0 1 . 9} & \text { Širenje znanosti. Popularizacija. Znanst.fant. } \\
\mathbf{0 0 1 . 9 4} & \text { Zabilježene pojave koje nisu u potpunosti razjašnjene } \\
\mathbf{0 0 1 . 9 5} & \text { [Namjerne znanstvene obmane i prijevare] } \\
\mathbf{1 3} & \text { [Filozofija uma i filozofija duha. Metafizika duhovnog života] }\end{array}$ \\
\hline Varijante anotacija & $\begin{array}{l}\text { Zdravko Vampovac u svojoj najnovijoj knjizi „Maleni ispod zvijezda“ propitkuje brojne } \\
\text { znanstvene teorije, među ostalima i one koje vezujemo uz najpoznatije svjetske znansvenike } \\
\text { poput Newtona i Einsteina. }\end{array}$ \\
\hline $\begin{array}{l}\text { Varijante prve } \\
\text { razine signature }\end{array}$ & $\begin{array}{l}00 \\
001 \\
001.9\end{array}$ \\
\hline
\end{tabular}

83 Bralić, I.; V. Barišić; V. Benjak; M. Brzović; S. Čulić; N. Đurašković; A. Gagro i suradnici. Cijepljenje i cjepiva. Zagreb: Medicinska naklada, 2017.

${ }^{84}$ Gawande, A. Bolja medicina: kako do djelotvornosti. Zagreb: Naklada Jesenski i Turk, 2014.

85 Blaser, M. J. Nestali mikrobi: kako prekomjerna uporaba antibiotika potiče moderne pošasti. Zagreb: Znanje, 2016.

${ }^{86}$ Vrhovac, B.; I. Aganović; B. Anić; V. Barbarić Babić; I. Bakran; I. Barić; B. Baršić i suradnici. Farmakoterapijski priručnik. 4. izd. Zagreb: Medicinska naklada, 2003.

$87 \mathrm{Na}$ slici su označene jezične pogreške, preuzete iz kataložnih zapisa ove publikacije (isticanja autorica članka). 
Među predmetnim odrednicama dodijeljenima ovom naslovu nalaze se „znanost - kritike“ te ,znanstvene obmane“ (vidi tablicu 6), iako je u prethodnom poglavlju obrazloženo da autor neke od znanstveno dokazanih tvrdnji ne opovrgava navodeći dokaze koji bi bili provjerljivi, nego iznosi teorije koje nisu ni znanstveno utemeljene ni dokazane.

Što se dodijeljenih klasifikacijskih oznaka tiče, oznaku 001.95 Namjerne znanstvene obmane i prijevare ovaj naslov, primjerice, dijeli s knjigom „Loša znanost ${ }^{\text {“88 }}$ britanskoga liječnika Bena Goldacrea u kojoj autor razotkriva zablude koje se serviraju konzumentima masovnih medija zloporabom znanstvenog diskursa, terminologije i metode.

Stručnu oznaku 001.9 s prve razine signature, pa tako i mjesto u slobodnom pristupu, ovaj naslov, paradoksalno, dijeli s knjigom „Kontraznanje: kako smo podlegli teorijama zavjere, nadriliječništvu, pseudoznanosti i kvazipovijesti““89 $u$ uvodnom dijelu spomenutoga britanskog sociologa Damiana Thompsona. Ta je situacija rezultat dvojakih kriterija dodjeljivanja iste klasifikacijske oznake: jedan je kriterij „o čemu je sadržaj dokumenta“ (,o obmanama“ / „o širenju ideja“), a drugi je kriterij „,̌̌to je sadržaj dokumenta“ („obmana“ / „,sirenje ideja“). Na proturječnu posljedicu takve knjižničarske prakse upozorava znanstvenik u citatu navedenom na početku ovoga rada.

\section{Zaključak}

Rezultati pretraživanja kataložnih zapisa odabranih pet primjera publikacija nevjerodostojne stručne građe u mrežnim katalozima triju integriranih knjižničnih sustava upućuju na to da knjižnice sadržajnom obradom i anotacijama ne prave razliku između vjerodostojne i nevjerodostojne stručne građe. Tako je korisnik izložen mogućoj dezinformiranosti o stručnoj, odnosno znanstvenoj utemeljenosti pojedine publikacije koja je dio knjižničnog fonda stručne građe.

Premda UDK nudi velik raspon mogućnosti označivanja različitih sadržaja dokumenata unutar pojedine struke ili znanosti, kao i mogućnost kombiniranja različitih područja, odnosno oznaka, ne postoji zasebna oznaka kojom se iskazuje nevjerodostojnost sadržaja dokumenta.

Jedna od mogućnosti označivanja jest uvođenje pomoćne oznake za unutarnji oblik, a oznaka bi se mogla kreirati kombiniranjem oznake (0:) s odgovarajućom glavnom UDK oznakom. Upotrebom takve oznake u kombinaciji s glavnim oznakama za sadržaj, dokumenti bi se mogli grupirati tako da budu raspoređeni prema predmetu kojim se bave, a istodobno bi bio iskazan njihov znanstveno neutemeljen i metodološki nesustavan pristup pojedinom fenomenu struke ili znanosti. Tako bi

88 Goldacre. B. Loša znanost. Zagreb: OceanMore, 2010.

89 Thompson, D. Nav. dj. 
se izbjegao paradoks da se istom klasifikacijskom oznakom označuju pseudoznanstvene publikacije i publikacije koje su kritika pseudoznanosti, tj. paradoks da se pretraživanjem mrežnih kataloga prema toj oznaci takvi naslovi dobiju u istom nizu rezultata, odnosno da u slobodnom pristupu publikacije s takvim dvama potpuno različitim sadržajima stoje jedna uz drugu pod oznakom „znanost općenito“.

Što se tiče predmetnog označivanja nevjerodostojne knjižnične građe, ,Pravilnik za predmetni katalog ${ }^{690}$ ostavlja mogućnost oblikovanja posebne tematske dodatne oznake iz kategorije oznaka kojima se izražava pristup, metoda, znanstveno ili neko posebno gledište.

Stoga bi bilo moguće oblikovati tematsku dodatnu oznaku koja bi glasila „osobno gledište" $\mathrm{i}$ koja bi se dodavala nakon predmetne oznake kojom se predmeti sadržaj dokumenta čiji autor nije znanstvenik ili stručnjak za pojedino znanstveno područje, a u kojoj on iznosi osobno gledište o jednoj ili više znanstvenih tema.

Informativnost i kvaliteta knjižničarskih anotacija nevjerodostojne stručne građe mogu se podići izrazima kojima se iskazuje da je sadržaj rezultat osobnoga autorova uvida u tematiku (,autor/autorica tvrdi/iznosi tezu/mišljenje/osobno viđenje“) te preciziranjem čitateljske publike kojoj je anotirani naslov ponajprije namijenjen.

Izostanak takvih navoda izlaže korisnika mogućoj dezinformiranosti o sadržaju građe, čemu dodatno pridonose nekritički oblikovane anotacije i one pisane po uzoru na nakladničke anotacije, a osobito anotacije koje sadržavaju tekst prepisan s korica publikacije, a kojemu je osnovna namjena predstavljanje sadržaja u svrhu prodaje.

U digitalnom okruženju u kojem su knjižnični katalozi mrežno dostupni, nužno je imati na umu dodatnu izloženost knjižničnih zapisa korisničkoj percepciji. Zbog mogućnosti da korisnici pretraživanjem klasifikacijskih i predmetnih oznaka stručnih publikacija dobiju brojne nerelevantne rezultate, važno je da narodne knjižnice imaju objavljene javno dostupne kriterije za nabavu knjižnične građe, kao i objašnjenje načina sadržajne obrade, odnosno klasifikacijskog i predmetnog označivanja te oblikovanja anotacija.

Sadržajnom obradom stručne građe, a osobito knjižničnim anotacijama, korisnicima je moguće dati informaciju o nevjerodostojnosti sadržaja stručne građe bez narušavanja etičkih načela koja se tiču razvoja i očuvanja intelektualnih sloboda pojedinaca te objektivnosti i neutralnosti pri prosudbi.

S obzirom na to da knjižnice imaju važnu ulogu u promicanju vjerodostojnih informacija i sprječavanju širenja lažnih vijesti, knjižničari se ne smiju oglušiti na upozorenja znanstvenika kad kažu:

„Čitatelji imaju pravo znati da ono što im se servira pod znanost (unatoč autoritetu knjižnica) u najvećoj mjeri nije znanost nego pseudoznanost, loša znanost i najčešće lažna znanost. " ${ }^{\text {"91 }}$

$90 \quad$ Usp. Štrbac, D.; M. Vujić. Nav. dj., str. 119-124.

91 Hrupec, D. Nav. dj., str. 176. 


\section{LITERATURA}

Anotacija. // Hrvatska enciklopedija. [citirano: 2020-06-05]. Dostupno na: https://www. enciklopedija.hr/Natuknica.aspx?ID=2895.

Barić, E.; L. Hudeček; N. Koharović; M. Lončarić; M. Lukenda; M. Mamić; M. Mihaljević i suradnici. Hrvatski jezični savjetnik. Zagreb: Institut za hrvatski jezik i jezikoslovlje: Pergamena: Školske novine, 1999.

Bawden, D.; L. Robinson. Supporting truth and promoting understanding: knowledge organization and the curation of the infosphere. // The Occasional Informationist: irregular thoughts on the information sciences. [citirano: 2020-04-05]. Dostupno na: https://theoccasionalinformationist.com/2018/07/17/supporting-truth-and-promoting-understanding-knowledge-organization-and-the-curation-of-the-infosphere/.

Etički kodeks Hrvatskog knjižničarskog društva. [citirano: 2020-10-01]. Dostupno na: https://www.hkdrustvo.hr/hr/eticki_kodeks/.

Hansson, S. O. Defining science and pseudoscience. // Philosophy of pseudoscience: reconsidering the demarcation problem / ed. by Massimo Pigliucci and Maarten Boudry. Chicago and London: The University of Chicago Press, 2013. str. 61-77. Dostupno i na: https://books.google.hr/books?id=Pc4OAAAAQBAJ\&lpg=PA61\&ots=wZFOsuv_Du\&d [citirano: 2020-06-20].

Horvat, J.; P. Ljevak; N. Tomašević; D. Gavranović. Književna kritika, nakladničke i knjižničarske anotacije u modernim i tradicionalnim medijima. // Arhivi, knjižnice, muzeji: mogućnosti suradnje u okruženju globalne informacijske infrastrukture 17(2014), 72-93. Dostupno i na: https://hrcak.srce.hr/ojs/index.php/akm/article/ view/3563 [2020-06-06].

Hrupec, D. Protiv nadnaravnoga: razmišljanja o istini, znanosti i knjigama. Zagreb: Kruzak, 2016.

Hrvatski UDK Online. [citirano: 2020-05-10]. Dostupno na: https://hr.udc-hub.com/hr/ login.php.

Kant, I. Was ist Aufklärung? // Utopie kreativ 159, 1(2004), str. 5-10. [citirano: 2020-0405]. Dostupno na: https://www.rosalux.de/fileadmin/rls_uploads/pdfs/159_kant.pdf.

Kuhn, T. S. Struktura znanstvenih revolucija. Zagreb: Naklada Jesenski i Turk: Hrvatsko sociološko društvo, 1999.

Leščić, J. Klasifikacija i predmetno označivanje: priručnik za stručne ispite. Zagreb: Dominović, 2012.

Leščić, J. Univerzalna decimalna klasifikacija: priručnik za knjižničare i shema za narodne knjižnice. Zagreb: Dominović, 2012.

Narodna knjižnica: IFLA-ine i UNESCO-ove smjernice za razvoj službi i usluga / priredila radna skupina Sekcije za narodne knjižnice na čelu s Philipom Gillom. Zagreb: Hrvatsko knjižničarsko društvo, 2003. 
Nebesny, T.; M. Švob. Izgradnja knjižne zbirke u narodnim knjižnicama. [citirano: 2020-05-05]. Dostupno na: http://dzs.ffzg.unizg.hr/text/nebesny_svob.htm.

18. okrugli stol o slobodnom pristupu informacijama - Knjižnice i alternativna (druga) istina. // Hrvatsko knjižničarsko društvo. [citirano: 2020-05-05]. Dostupno na: https://www.hkdrustvo.hr/hr/skupovi/skup/381/.

Pavić, Ž. Science and pseudoscience in postmodern societies. // Informatologia 46, 2(2013), 145-153.

Petr Balog, K.; I. Majlinger Tanocki. Dosljednost predmetnog označivanja elektroničke građe u mrežnim katalozima hrvatskih narodnih knjižnica. // Vjesnik bibliotekara Hrvatske 57, 1-3(2014), 69-103. Dostupno i na http://hrcak.srce.hr/142252 [citirano: 2020-10-03].

Polšek, D. Two ways of dealing with scientific fraud. // Revija za sociologiju 28 3-4(1997), 163-173.

Popper, K. R. Logika naučnog otkrića. Beograd: Nolit, 1973.

Post-truth. // Cambridge Dictionary. [citirano: 2020-05-18]. Dostupno na: https://dictionary.cambridge.org/dictionary/english/post-truth.

Pravilnik i priručnik za predmetne odrednice. Verzija 1. Zagreb: Nacionalna i sveučilišna knjižnica, 2019. [citirano: 2020-04-18]. Dostupno na: http://ps.nsk.hr/wp-content/uploads/2019/09/Pravilnik-i-priru\%C4\%8Dnik-za-predmetne-odrednice-srpanj-2019-v2.pdf.

Predmetni sustav Nacionalne i sveučilišne knjižnice u Zagrebu. [citirano: 2020-04-20]. Dostupno na: http://ps.nsk.hr/o-predmetnom-sustavu/.

Prosvjetiteljstvo. // Hrvatska enciklopedija. [citirano: 2020-04-05]. Dostupno na: https:// www.enciklopedija.hr/Natuknica.aspx?ID=50722.

Pseudo-science. // Cambridge English Dictionary. [citirano: 2020-06-20]. Dostupno na: https:/dictionary.cambridge.org/dictionary/english/pseudo-science.

Rončević, I. Prepoznavanje pseudoznanstvenih tvrdnji. // Ideje.hr. [citirano: 2020-1001]. Dostupno na: http://ideje.hr/prepoznavanje-pseudoznanstvenih-tvrdnji.

Špiranec, S. Knjižnice u dobu post-istine: etičke i epistemološke dileme. // Slobodan pristup informacijama: 18. okrugli stol: zbornik radova / uredile Davorka Pšenica i Annemari Štimac. Zagreb: Hrvatsko knjižničarsko društvo, 2018. Str. 35-48.

Špiranec, S. Subjektivna paradigma sadržajnog označivanja. // Vjesnik bibliotekara Hrvatske 57, 1-3(2014), 1-14. Dostupno i na: https://hrcak.srce.hr/142161 [citirano: 2020-10-03].

Štrbac, D.; M. Vujić. Pravilnik za predmetni katalog. Zagreb: Knjižnice grada Zagreba, 2004.

Tadić, K. Rad u knjižnici. Opatija: Naklada Benja, 1994. 
Thompson, D. Kontraznanje: kako smo podlegli teorijama zavjere, nadriliječništvu, pseudoznanosti i kvazipovijesti. Zagreb: Algoritam, 2009.

Science and pseudo-science. // Stanford Encyclopedia of Philosophy. [citirano: 202010-01]. Dostupno na: https://plato.stanford.edu/entries/pseudo-science/.

ZKD Forum - Umijeće laganja. // Zagrebačko knjižničarsko društvo. [citirano: 202005-05]. Dostupno na: https://zkd.hr/novosti/zkd-forum-umijece-laganja/.

Znanost. // Hrvatska enciklopedija. [citirano: 2020-06-20]. Dostupno na: https://www. enciklopedija.hr/Natuknica.aspx?ID=67353.

\section{LITERATURA KORIŠTENA ZA PRIMJERE}

Aljinović, Z.; B. Marasović, B. Šego. Financijsko modeliranje. 2. izmijenjeno i dopunjeno izd. Split: Ekonomski fakultet Split Sveučilišta, 2011.

Blaser, M. J. Nestali mikrobi: kako prekomjerna uporaba antibiotika potiče moderne pošasti. Zagreb: Znanje, 2016.

Bralić, I.; V. Barišić; V. Benjak; M. Brzović; S. Čulić; N. Đurašković; A. Gagro i suradnici. Cijepljenje i cjepiva. Zagreb: Medicinska naklada, 2017.

Bučević, A. Biti i imati: promjenom vibracije do financijske slobode. Split: Kontakt plus, 2018.

Ceci, S. Blesimetar Drugi: šest godina stariji, nimalo pametniji. Zagreb: In.Tri, 2019.

Cirkveni, T.; N. Dremel; Š. Guzić; K. Horvat Jurjec; Đ. Jurić; Lj. Markota; Z. Trcović i suradnici. Blagajničko poslovanje i fiskalizacija. [2. izd.]. Zagreb: RRiF plus, 2013.

Gawande, A. Bolja medicina: kako do djelotvornosti. Zagreb: Naklada Jesenski i Turk, 2014.

Goldacre. B. Loša znanost. Zagreb: OceanMore, 2010.

Goleman, D. Emocionalna inteligencija: zašto može biti važnija od kvocijenta inteligencije. [9. izd.]. Zagreb: Mozaik knjiga, 2017.

Može li se oprostiti nakon rata: psihologijski pogled. // 25. Ljetna psihologijska škola studenata i nastavnika Odsjeka za psihologiju Filozofskog fakulteta u Zagrebu / urednici Čorkalo Biruški, D.; D. Ajduković; A. Löw; H. Bakić. Zagreb: Filozofski fakultet Sveučilišta u Zagrebu: FF press, 2016. str. 1-144.

O’Hear, A. Uvod u filozofiju znanosti. Zagreb: Hrvatski studiji, 2007.

Pepeljnjak, B. Znanstveno - potpuno objašnjenje čovjeka: sreća, stres, osjećaji i razum. Zagreb: vlast. nakl., 2018.

Rathus, S. A. Temelji psihologije. Prijevod 5. izd. [izvornika]. Jastrebarsko: Naklada Slap, 2001.

Rhonda Byrne: biography of the author. [citirano: 2020-05-18]. Dostupno na: https:// www.thesecret.tv/about/rhonda-byrnes-biography/. 
Royal, L.; K. Priest. Prizma Lyre: istraživanje ljudskog galaktičkog podrijetla. Bregana: Harša, 2018.

Rudan, I. Točna boja neba: razmišljanja o znanosti u 21. stoljeću. Zagreb: Naklada Ljevak, 2017.

Thompson, D. Kontraznanje: kako smo podlegli teorijama zavjere, nadriliječništvu, pseudoznanosti i kvazipovijesti. Zagreb: Algoritam, 2009.

Vampovac, Z. Maleni ispod zvijezda: knjiga o znanstvenim obmanama. Vodice: vlast. nakl., 2018.

Vrhovac, B.; I. Aganović; B. Anić; V. Barbarić Babić; I. Bakran; I. Barić; B. Baršić i suradnici. Farmakoterapijski priručnik. 4. izd. Zagreb: Medicinska naklada, 2003.

Vujnović-linkovi. // Omega lan. [citirano: 2020-08-05]. Dostupno na: https://www.omegalan.info/vujnovic-linkovi/.

Vujnović, D. Zbogom cjepiva: štetna i neučinkovita. Zagreb: Omega lan, 2018.

Zoričić, Z. Ovisnosti: prevencija, liječenje i oporavak. Zagreb: Školska knjiga, 2018. 